\title{
BOOKS AND THEIR CREATORS FROM THE MEDIEVAL KINGDOM OF HUNGARY AT THE UNIVERSITY OF PRAGUE
}

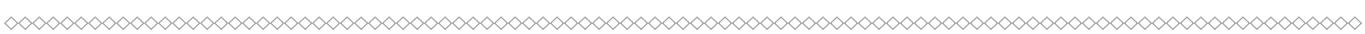

Péter HARASZTI SZABÓ

\author{
Eötvös Loránd University \\ Institute of History \\ Department of Medieval and Early Modern History of Hungary \\ Kossuth Lajos square 1-3 \\ 1055 Budapest \\ Hungary \\ szabo.szpeter@hotmail.com
}

HARASZTI SZABÓ, Péter. Knihy a ich autori zo stredovekého Uhorského král'ovstva na univerzite v Prahe. V centre záujmu uhorských študentov na univerzite v Prahe neboli filozofické texty, a to aj napriek skutočnosti, že väčšina z nich študovala na artistickej fakulte. Analýza skúmaných textov dokazuje, že uhorskí študenti sa zaujímali prevažne o teológiu, nakol'ko viac ako polovica zachovaných a známych rukopisov (prípadne ich kópií) spadala pod túto disciplínu. Aj napriek nedostatku zdrojov, možno predpokladat', že v hlavnom meste Čiech boli študenti teológie aj z Uhorska. Ďalším záverom je, že si prostredníctvom týchto textov husitské myšlienky nemohli nájst' cestu do Uhorska. Iba jeden fragment by mohol byt’ spájaný s husitstvom, takzvaná „husitská Biblia“, ale je to jedna z najviac problematických písomností z hl'adiska jej datácie, pôvodu a prekladatel'ov. Teologické rukopisy boli obvykle prepisované s ciel'om pomôct' kňazom viest' veriacich v ich každodennom živote a pomôct' im v rôznych cirkevných záležitostiach. Právne texty Lőrinca Zámbóa poukazujú práve na tento spôsob ich využitia. Stojí za to poznamenat', že v rovnakom čase, ked' vznikli tieto pražské spisy, hrali dôležitú úlohu v cirkevných súdnych miestach v Ostrihomskej arcidiecéze právne texty prepošta Lőrinca a spis Processus iudiciarius. Možno sa domnievat', že prepošt János z Vesprému (1367-1382) tiež študoval právo v Prahe v 60. rokoch 14. storočia, je to však iba predpoklad. Dva najdôležitejšie kódexy pochádzajú od Miklósa Feystripa a „reverenda Budu“. Analýza Feystripovho kódexu odhalila kultúrne vplyvy (aspoň z určitého smeru) knižnice Bratstva 24 spišských farárov. Rukopis reverenda Budu by mohol súvisiet' so zakladatel'om Collegia Christi alebo tento rukopis patrí doposial' neznámemu uhorskému študentovi.

Kl'účové slová: knihy; stredovek; Uhorské král'ovstvo;

Keywords: Books; Middle Ages; Kingdom of Hungary;

\section{Introduction}

The University of Prague ${ }^{1}$ unequivocally was one of the most important educational institutions in the Middle Ages, if not the first in its region. ${ }^{2}$ Thus the stu-

1 The Researches were maintained by the MTA-ELTE Academical Researches Group (213TKI738).

2 I would like express my gratitude to Kinga Körmendy and Farkas Gábor Kiss to their advices during my researches! 
dents of Prague were came not only from Bohemian, but also from the Germanspeaking lands and even from the Hungarian Kingdom, the Polish Kingdom and the Baltic region. Unfortunately has not survived an exact and accurate list of the Hungarian students. It is well known that the matriculation lists of the University of Prague have lost during the Second World War. Thanks to the researches of the History of Universities Research Group of the Hungarian Academy of Sciences and Eötvös Loránd University we are able to enumerate 251 matriculations from the Hungarian Kingdom to the University of Prague during the Middle Ages. ${ }^{3}$ Around two-thirds of them were educated at the Faculty of Arts, while only cc. 60 students can be found at the independent Law University. The number of the students of the Faculties of Theology and Medicine are estimated, because the sources, concerning the matriculation of these faculties, are entirely lost. This is an aching disadvantage because this was the only university in Central Europe which had theology faculty for a long time. After the establishing of theology faculty at the University of Vienna, the faculty of Prague could retain the leading role in Central Europe. ${ }^{4}$

Hence we have insufficient information about the theological studies or interests of the Hungarian students. Although, there is one way which can help us to get closer to the resolution. Various books, writings and manuscripts were copied and used by the Hungarian students. The investigation of the using of these writings can bring new results on the theological interests of the students as well as on the impact of Hussites to Hungary. Moreover, it can contributes to the survey of the spiritual roots of medieval educational and "cultural" institutes of the contemporary Hungary. But in this article I take into consideration only those texts, which was made and used by Hungarian students.

At this step of my researches there are fourteen books which can be analysed from this point of view, but one volume from them, only with restrictions connected to a Hungarian student of Prague. The provenience, the marginal notes and the copiers of these books can help to draw the intellectual streams of the University of Prague at the turn of the $14^{\text {th }}$ and $15^{\text {th }}$ centuries.

\section{Philosophical and legal texts from the University}

As it was mentioned above, the majority of the Hungarian students studied at the Faculty of Arts. In spite of this fact, not the philosophical manuscripts created the biggest group within the fourteen codices, since only three texts belong to them. The first is the De anima and some other, minor tractates (De somno et vigilia et alii) of Aristotle about natural sciences, which were copied by Johannes Ungarus de Wardino. ${ }^{5}$ The exact time of copying is not known, although the place of these

3 HARASZTI SZABÓ, Péter. Magyarországi diákok a Prágai Egyetemen a középkorban. In HARASZTI SZABÓ, Péter - KELÉNYI, Borbála - SZÖGI, László. Magyarországi diákok a Prágai és a Krakkói Egyetemeken I. Budapest: ELTE Levéltár, MTA-ELTE Egyetemtörténeti kutatócsoport, 2016, pp. 9-42.

4 KADLEC, Jaroslav. The Theological Faculty, In ČORNEJOVÁ, Ivana. - SVATOŠ, Michal. - SVOBODNÝ, Petr. A History of Charles University. Prague: Karolinum Press, 2001, p. 126.

5 TǨ́ŠSKA, Josef (ed.). Životopisný slovník předhusitské pražské univerzity, 1348-1409. Praha: Univerzita Karlova, 1981, p. 318. 
works in the university's curriculum helps us to ascertain it. According to the statutes of the university the "On soul" had to be learnt at least for three months, ${ }^{6}$ moreover this text was prescribed for those who wanted to gain the Bachelor degree. ${ }^{7}$ In contrast to the De somno et vigilia and other tracts which were recommended to the magister artium degree ${ }^{8}$ (although these texts were closely linked to the De anima). Johannes Ungarus gained the licentiatus artium grade at $4^{\text {th }}$ March in $1384 .{ }^{9}$ It means that he had to learn these works before his upcoming master's graduation, thus the manuscript was copied around 1384 or a little bit later. John copied these writings obviously in order to study them, while the texts remained in Bohemia, the copier most probably sold them, which was usual in this period.

From the three philosophical texts, two writings related to the treatises of Aristotle, which reflects to the fame of the antic author. The second from these texts is entitled to Questiones super Metaphysicam Aristotelis, was the work of the famous Marsilius ab Ingen, now hold in the National Library of Austria. ${ }^{10}$ It is known that this writing was copied by Petrus de Spinis in 1409, because in an inscription the copier revealed himself. While another inscription tells us that there was a time when this manuscript belonged to another student, namely Ladislaus de Czap. Both of them studied at Prague, although after receiving the Bachelor degree only Petrus de Spinis studied in Vienna. He gained the Bachelor title at Prague in 1410, which confirms the assumption that he made this copy in Prague. How could this manuscript transferred to the property of Ladislaus? After Ladislaus became licentiatus artium in 1410 (with the assistance of Petrus de Brandis who supported Petrus, too $)^{11}$ came home to Hungary and began his career as a notary at the palatinate seat, thus he had never studied at Vienna. The only solution is that Ladislaus ordered this copy from his fellow student, Petrus, in order to use this text to train himself for his exam. After the successful exam, Ladislaus left the writing to Petrus, who later went to Vienna with the manuscript, most probably to gain a higher academic grade. This explains how could been this manuscript in the hands of two students within a short period (1409-1410) and how could this writing get to Vienna. I analyse the last philosophical text later.

Two (or maybe three) Hungarian students' writings belonged to the second biggest Faculty of the university, the Faculty of Law (from 1372 a whole independent Law University). The University of Prague took the first place among the Hungarian students regarding the peregrination from the perspective of legal

\footnotetext{
6 GERZABEK, Johannes Nepomuk (ed.). Liber Decanorum Philosophicae Universitatis Pragensis ab anno 1367. Usque ad annum 1585. E Codice membranaceo illius Aetatis nunc primum luce donatum. I-II. Pragae, 1830-1832. I, p. 76. (Later: LDPP)

7 LDPP I., pp. 48-49.

8 LDPP I., p. 56.

9 LDPP I., p. 219.

10 CSAPODI, Csaba - CSAPODINÉ GÁRDONYI, Klára (ed.). Bibliotheca Hungarica. Kódexek és nyomtatott könyvek Magyarországon 1526 előtt. I-III. Budapest: Akadémiai Kiadó, 1988-1994. I. No. 208.; Österreichische Nationalbibliothek, Wien, Cod 5297 Han, http:/ / data.onb.ac.at/rec/ AL00168911.

11 LDPP I. 406, p. 408.
} 
studies in the second half of the $14^{\text {th }}$ century. Until the university had worked, more Hungarian students learned law in Prague than in Vienna, Bologna or Padua. Nonetheless if one sums up all of the Italian universities, the Apennine peninsula leads the imaginary list regarding the preferences of the Hungarian Law students at the turn of the $14^{\text {th }}$ and $15^{\text {th }}$ centuries. One of the above mentioned manuscripts was the work of Thomas de Pijesczano, the well-known first student of the Collegium Christi of Esztergom, who began his university studies at Prague in 1395 and get a doctoral degree of canon law in $1402 .{ }^{12}$ He copied an exemplar of the famous - but in the Hungarian historiography less explored - Processus iudiciarius, which was written by Nicholaus Puchník, the later Archbishop of Prague in the second half of 1380's. ${ }^{13}$ János Csontosi, the 19th-century historian brought some light on this manuscript and some others which were copied from this, ${ }^{14}$ while Gyula Gábor cleared some misunderstanding about the text. ${ }^{15}$ Later Kinga Körmendy summarised the information related to the Processus. ${ }^{16}$ Péter Erdő emphasized that the medieval Hungarian ecclesiastical courts used mainly foreign authors' ordo iudiciarius. The Hungarian jurists adapted these ordos and conformed to the Hungarian circumstances, which is clearly visible in the copy of Thomas de Pijesczano. ${ }^{17}$ This copy was most probably written in Prague and ordered by Pijesczano' master, Johannes de Buda. The reviser of the manuscript replaced the toponyms of the archdiocese of Prague to the toponyms of the archdiocese of Esztergom. Two other manuscripts was copied from the text of Pijesczano which were in Göttingen ${ }^{18}$ and in Königsberg (Kaliningrad, RU). In addition three other manuscripts can be found at Leipzig and one at the cloister of St. Florian in Austria. ${ }^{19}$ Unfortunately the manuscript of Königsberg was lost, but according to the literature the codex originated from Bautzen and dated to 1405-1406. ${ }^{20}$ Recently Dominic Budsky dealt with the manuscripts of Processus. He linked one of the manuscripts of Leipzig to Jacobus de Radewitz through a possessor

12 KÖRMENDY, Kinga. Studentes extra regnum - Esztergomi kanonok egyetemjárása és könyvhasználata a középkorban. Budapest: Szent István Társulat, 2007, pp. 184-185; C. TÓTH, Norbert. Az esztergomi székeskáptalan a 15. században. I. rész: a kanonoki testület és az egyetemjárás. Budapest: Magyar Tudományos Akadémia-Hadtörténeti Intézet és Múzeum-Szegedi Tudományegyetem-Magyar Nemzeti Levéltár Országos Levéltára Magyar Medievisztikai Kutatócsoport, 2015. I. 95, 100, p. 118.

13 Tř́í̌KKA, Josef. Př́ispěvky k stř̌edověké literární universitě. In Acta Universitatis Carolinae - Historia Universitatis Carolinae 9 (1968) - 10 (1969), p. 46.

14 Múzeumi könyvtári tisztviselők búvárlatai 1885-ben. Magyar Könyvszemle, 1885, vol. 10, no. 1-6, p. 274.

15 GÁBOR, Gyula. Adatok a középkori magyar könyvírás történetéhez. In Magyar Könyvszemle, 1912, vol. 20, no. 3, pp. 308-313.

16 KÖRMENDY, Kinga. Az esztergomi Collegium Christi és könyvtára a XIVXVI. században. In Magyar Könyvszemle, 1983, vol. 99, no. 1, p. 17.

17 ERDÓ, Péter. Egyházjog a középkori Magyarországon. Budapest: Osiris, 2001, 94 pp. Although Erdő stated that Pijesczano copied the Processus in Esztergom, most probably he made this copy in Prague.

18 Niedersächsische Staats- und Universitätsbibliothek, Göttingen, Luneb 48.

19 Ld. 11. lábjegyzet.

20 BUDSKÝ, Dominik. Processus iudiciarius secundum stilum Pragensem Mikuláše Puchníka (Rozbor dochovaných rukopisů). In Studie o Rukopisech 2009, 39, s. 260. 
inscription. ${ }^{21}$ Radewitz studied at the University of Law in Prague in 1397, exactly at the same time when Pijesczano also studied there. ${ }^{22}$ Thus probably Radewitz got the manuscript from Pijesczano or inversely. The data help us to close the old debate about the provenience of the manuscript copied by Pijesczano. It seems that he copied the text in Prague not in Esztergom. Interesting addition to the origin of the copy of Pijesczano that he studied in Prague exactly at the same time when Puchník worked as the vicar general of the Archbishop of Prague. Perhaps the analysis of the Göttingen manuscript (which, surprisingly, Budsky hasn't mentioned) helps us to determine whether the copy of Pijesczano was in use at the spiritual seat of the archdiocese of Esztergom or not. It's beyond doubt that Pijesczano was a delegate or associate judge for several occasion, while on the top of that he was vicar general of Esztergom between 1423 and 1425. ${ }^{23}$

Lawrence Zámbó of Mezólak from the Pápa genus was another jurist, who copied several legal texts, which were remained to posterity. His family was at the zenith of their power in the 14th century, his father and his uncle, Nicholas was also raised at the royal court, and Nicholas died as magister tavernicorum regalium..$^{24}$ Lawrence matriculated in the Law University of Prague as prepositus Posoniensis in $1383 .{ }^{25}$ The texts, copied or ordered by him, can be found nowadays in the Rare Books and Early Manuscripts Department of Harvard Law School. ${ }^{26}$ The texts fill out the two-third part of the whole codex. ${ }^{27}$ David Jenkins supposed that Provost Lawrence used this texts during his studies. The researchers can identify more than one handwritings, thus the provost probably hired ${ }^{28}$ someone

21 BUDSKÝ, ref. 20, pp. 259-60.

22 Tर̌́̌́̌̆KA, ref. 5, p. 207.

23 C. TÓTH, Norbert - LAKATOS, Bálint - MIKÓ, Gábor. A pozsonyi prépost és a káptalan viszálya (1421-1425). A szentszéki bíráskodás Magyarországon - A pozsonyi káptalan szervezete és múködése a XV. század elején. Budapest: Magyar Tudományos Akadémia-Hadtörténeti Intézet és Múzeum-Szegedi Tudományegyetem-Magyar Nemzeti Levéltár Országos Levéltára Magyar Medievisztikai Kutatócsoport, 2014, 32, p. 233.

24 ENGEL, Pál. Magyarország világi archontológiája I-II. Budapest: MTA Történettudományi Intézet, I., p. 38.

25 C. TÓTH, Norbert. A székes- és társaskáptalanok prépostjainak archontológiája 1387-1437. Budapest: Magyar Tudományos Akadémia-Hadtörténeti Intézet és Múzeum-Szegedi Tudományegyetem-Magyar Nemzeti Levéltár Országos Levéltára Magyar Medievisztikai Kutatócsoport, 2013, s. 58. Although according to C. Tóth he was provost only from 1384, it is clear thanks to the documents of the University of Law in Prague that he was already provost a year earlier. See: SPURNY, Johannes (ed.). Album seu Matricula Facultatis Juridicae Universitatis Pragensis ab anno Christi 1372 ad annum1418 E Codice membranaceo illius Aetatis nunc primum luce donatum, plenoque nominum indice auctum: Codex diplomaticus Universitatis eiusdem: originem, incrementa, privilegia, iura, benefica...cui item personarum rerumque index, atque...imagines exhibentes subnecuntur. Pragae, 1834, pp. 37-38. (Later: AJP).

26 Harvard Law School, MS 189.

27 JENKINS, David. The Identification of Harvard Law School Ms 189. In Law Library Journal, 1992, 1, p. 41.

28 Provost Lawrence ordered another work, a codex which contained the writings of Bartholomeus de Sancto Concordio, but this only from 1425 was in the catalogue of the chapter' library. SOPKO, Julius. Stredoveké latinské kódexy v slovenských knižniciach. Martin: Matica Slovenská, 1981. No. 56.; Vö.: ŠEDIVÝ, Juraj. Mittelalterliche Schriftkultur im Pressburger Kollegiatkapitel. Bratislava: Chronos, 2007, pp. 114-115. 
to copy some parts of the texts for him. ${ }^{29}$ Juraj Šedivý published the list of the texts of the codex, which includes the works of Paulus Hungarus, Galvano da Bologna or the highly popular authors of Bohemia, Guillelmus Horborch and Stephanus de Rudnice. ${ }^{30}$ These writings helped to the clergy in the daily practical measures such as marriage, funeral, excommunication, interdict, usury or any misuse of priests, etc. In other words, Provost Lawrence, - as Jenkins and Miriam Hlavačková have also mentioned -, wanted to use these legal texts in order to settle the spiritual issues his Provostry according to the canonical regulations. ${ }^{31}$ This fact lightens why the sources about the judicial actions of the provosts of Bratislava appear during the time of Provost Lawrence after the time of 1310s. ${ }^{32}$

It worth to mention a third manuscript, which is already known among scholars. This is the copy of the commentary written to the Decretals of Pope Gregory IX, which was copied by Petrus Ungarus de Lebeta at Prague in 1424. ${ }^{33}$ One cannot find Petrus' name in the university's sources. Moreover the education in the University of Prague was banned by Pope Martin V. from 1418 because the city was pressed by religious conflicts in the $1420 \mathrm{~s} .{ }^{34}$ In addition Peter studied in Leipzig in $1423 .{ }^{35}$ However, the University of Prague was less attractive to the students in that time, the wealthy libraries exerted considerable attraction to the intellectuals, like Peter.

This is all we know about the philosophical and legal manuscripts relating to the Hungarian students in the Middle Ages at Prague. This low number also points out that most of the examined texts represent the two less-known faculties. Although the University of Prague was the main centre of the theology studies in the region. ${ }^{36}$ The Central European students only had opportunity to study theology in Prague until the 1380s, when the Theology Faculty of Vienna opened its doors to the inquirers. ${ }^{37}$ The main centre of theology studies was Paris in medieval Europe, in contrast to the information about this university education, the historians only know fragments about Prague. However these data also bring some light upon important factors.

29 JENKINS, ref. 27, p. 42.

30 HLAVAČKOVÁ, Miriam. Kapitula pri dóme Sv. Martina - Intelektuálne centrum Bratislavy 15. storočí. Bratislava: Spoločnost' Pro Historia, 2008, p. 54, (214. lbj.).

31 JENKINS, ref. 27, pp. 41-42; HLAVAČKOVÁ, 2008, p. 54.

32 C. TÓTH- LAKATOS - MIKÓ, ref. 23, 52, p. 60.

33 CSONTOSI, János. Adalék a magyarországi XIV-XV. századi könyvmásolók és betúfestők történetéhez. Magyar Könyvszemle 1879, 4, 1, p. 49. (Later: CSONTOSI, 1879.); CSAPODI, Csaba CSAPODINÉ GÁRDONYI, Klára (ed.). Bibliotheca Hungarica. Kódexek és nyomtatott könyvek Magyarországon 1526 előtt. I-III. Budapest: Akadémiai Kiadó, 1988-1994. II. No. 1960. (Later: CSAPODI-CSAPODINÉ); Universitätsbibliothek Leipzig, MS 1066.

34 SVATOŠ, Michal. The studium generale 1347/8-1419. In ČORNEJOVÁ, Ivana - SVATOŠ, Michal. - SVOBODNÝ, Petr. A History of Charles University. Prague: Karolinum Press, 2001, p. 88.

35 ERLER, Georg (ed.). Die Matrikel der Universität Leipzig I.- III. Leipzig: Giesecke\&Devrient, 1895, I, p. 75.

36 BRANDT, Hans Jürgen. Universität, Gesellschaft, Politik und Pfründen am Beispiel Konrad von Soltau (†1407). In IJSEWIJN, Jozef - PAQUET, Jacques (ed.). The Universities in the Late Middle Ages. Les universités à la fin du Moyen Âge. Louvain: University Press, 1978, p. 618.

37 TONK, Sándor. Erdélyiek egyetemjárása a középkorban. Bukarest: Kriterion, 1979, p. 30. 


\section{Theological and Medical interests of the Hungarian students}

From the examined fourteen codices, seven contain theological writings, while one medical text. The only medical writing related to Nicolaus de Zilina. Nicholas studied at the Faculty of Arts of Prague in 1420, although as far as we know he didn't receive a degree. ${ }^{38}$ Nevertheless he certainly stayed at Prague. He may be identical with a student whom was mentioned in the Dean's book of the Faculty of Arts from 1429. ${ }^{39}$ The pope prohibited the education and graduation at Prague in 1418, thus it's possible that Nicholas could completed his studies only in 1429 , when the education restarted thanks to the pope's regulation. ${ }^{40}$ His two manuscripts also prove that he stayed at Prague. The first is the Liber urinarum of Isaac Iudaeus. ${ }^{41}$ This Arabic medical work was compiled in the 9- $11^{\text {th }}$ century and later was translated by Constantinus Africanus into Latin in the $11^{\text {th }}$ century. ${ }^{42}$ The codex contains many other authors' medical texts (Hippocrates, Avicenna, Rhazes, etc.), but according to a short inscription (fol. 252r.) Nicholas copied only a cc. 40 folio-long text in 1431. This note also reveals that Nicholas was one of the few foreign people at Prague who attended to the Charles College, since he copied this text in the Carolinum, although he was the chaplain of the King Wenceslas College in $1415 .{ }^{43}$ His other manuscript points to his various interests, because he wrote a short prologue to the Homilies of Paulus Diaconus in $1420^{44}$. He later became a professor at the Faculty of Arts.

Two writings differ to the other theological texts, since these reflect to the Hussite movement. Mathias de Zolio copied the Rosarius sive Floretus minor in 1417. ${ }^{45}$ Mathias was the student of the University of Vienna in $1401,{ }^{46}$ but he studied at Prague in 1409, at the latest. He had never left the university or the city. He get the atrium baccalareus title in 1410, six years later he received the licentiate, too. ${ }^{47}$ One more year later he copied one of the work of John Wyclif. The English reformer's explanations and glosses to the Holy Scriptures, which was made between 1384 and 1396. Wyclif collected and edited his text together with his students, which includes explanations of Biblical people, ecclesiastical and theological thoughts and practices, as well as ethical and moral inscriptions. Furthermore he collected and interpreted notes and glosses to the scripts of the Church Fathers, Scholastics, Canonists and Biblical people's thoughts about the

38 LDPP, II, p. 2.

39 LDPP, II 6, 15, 16, p. 22.

40 SVATOŠ, Michal. The utraquist university. In ČORNEJOVÁ, Ivana - SVATOŠ, Michal - SVOBODNÝ, Petr. A History of Charles University. Prague: Karolinum Press, 2001, p. 189.

41 TRUHLÁ̌̌, Josef. Catalogus codicum manu scriptorum latinorum, qui in c. r. bibliotheca publica atque Universitatis Pragensis asservantur I. Pragae: Sumptibus Regiae Societatis Scientiarium Bohemicae, 1905, pp. 583-584. (National Library of Czech Republic, VIII F 18).

42 RASHDALL, Hastings. The History of universities I-II, Oxford: Clarendon Press, 1895, I., p. 96. DEMAITRE, Luke. Medieval Medicine: The Art of healing, from head to toe. Praeger, 2013, pp. 11-12.

43 National Library of Czech Republic, V H 21, f 82a.

44 National Library of Czech Republic, V G 25.

45 TŘÍŠKA, Josef. Literární cinnost predhusitské university. Praha: Univerzita Karlova, 1967, p. 108.

46 TÜSKÉS, Anna. Magyarországi diákok a bécsi egyetemen 1365-1526. Budapest: ELTE Levéltár, 2008, 71. Vö.: TŘÍŠKA, ref. 5, p. 368.

47 LDPP I. 414, p. 437. 
ecclesiastical law. ${ }^{48}$ The copy of Mathias is only a shorter extract of Wyclif's work. This writing is known in three version: the complete is the Floretus, the mid-long is the Rosarius sive Floretus minor, while the shortest version is the Rosarium. ${ }^{49}$ Mathias de Zolio - like Nicolaus de Zilina - was a magister of the Carolinum. He bought a house near the main square of the Old Town of Prague in 1428, three years later he copied the Holy Bible. According to Josef Třiška, Mathias died in Prague around $1454 .{ }^{50}$ Rosarius sive Floretus minor is the only text within the examined manuscripts which certainly sympathised with the thoughts of the Hussites. Neither the text nor the author took part in the propagation of the Hussitism in Hungary, since the copier died in Prague thus the manuscript stayed in the next 500 years there. Thus, the examination of this codex warns us that the university was not the only medium which could have propagated the Hussite ideas towards Hungary, but further research is needed.

It is important to speak briefly about the so called "Hussite Bible" and its translators. ${ }^{51}$ The first Hungarian translation of the Bible (in three fragments) contains obvious Hussite references in it, which refers to Prague. Hungarian medievalists have noticed this long time ago, ${ }^{52}$ although its Hussite origin was queried many times. ${ }^{53}$ However among others, György Galamb recently testified the Hussite connections of the translations and the translators. ${ }^{54}$ The question remains whether the translators obtained their information about Hussitism at first or second hand. Traditionally the translators, priests Valentine and Thomas identified as Thomas de Quinqueeclesiis and Valentinus de Vylak, although this identification based upon that their first names correspond with the aforementioned people, who studied at Prague. This argument is not strong enough, thus the identification is not acceptable and until we couldn't identify the translators we can't assume that the Prague University had any direct effects on this matter in this early period. ${ }^{55}$ That is why this text only partly related to this research.

A certain Nicholas was the copier of a text, which was made at Prague in 1376. This script contains several texts: one Martyrologium, a short tractate about the sins, and a Czech-related fragment of letter. The next text is the Tractatus de religione of Thomas Hibernicus, while the second half of the codex contains sermons and the Europe-wide famous Legenda Aurea by Jacobus de Voragine.${ }^{56}$ Fortunately, the copier wrote his name and the datum in his work (fol.208v), thus it is known, that a certain Nicholas made the copy of these texts at Prague in 1376. One barely could identify Nicholas and only partially can be linked his name (and his work)

\footnotetext{
48 HUDSON, Anne. Selections from English Wycliffite writers. Toronto: University Press, 1997, p. 7.

49 LAHEY, Stephen E. (ed.). Wycliff: Trialogus. Cambridge: University Press, 2013, p. 15.

50 Tř́́̌́KA, ref. 5, p. 368.

51 Codex of Münich: Bayerische Staatsbibliothek, München, Cod. Hung. 1.; Codex of Vienna: National Library of Hungary, Budapest, MNy 72.; Apor Codex: Székely National Museum, Sfântu Gheorghe, A 1330.

52 JAKUBOVICH, Emil - PAIS, Dezső. Ómagyar olvasókönyv. Pécs, 1929, p. 248.

53 TÍMÁR, Kálmán. Legrégibb magyar bibliánk naptára és helyesírása. Kalocsa, 1931, p. 3.

54 GALAMB, György. A Huszita biblia és a ferencesek. Megjegyzések az eső magyar bibliafordítás kérdéséhez. In Egyháztörténeti szemle, 2009, vol. 10, no. 2, pp. 3-12.

55 HARASZTI SZABÓ, ref. 3, p. 38.

56 SOPKO, ref. 28, No. 207.
} 
to the university. Julius Sopko, - quoted to Emma Bartoniek - informs that the codex was the property of the chapter of Bratislava in 1686, and it was in use in the early modern and even in medieval time, too. ${ }^{57}$ Only one student, Provost Lawrence, is known from Bratislava at the University Prague in the Middle Ages. The other opportunity that the copier later became the member of this chapter since the whole ranks of the chapter in not known. If one of the known students was the copier, he might been Nicolaus de Buda (in 1377 at the Law University) ${ }^{58}$ or Nicolaus canonicus Colocensis (in 1375 at the Law University) ${ }^{59}$ or Nicolaus de Czypcz. The latter was "ain guet ler von der mess" anyway. ${ }^{60}$

The library and the possible intellectual prefiguration of the Fraternity of the 24 parish priests of Spiš

One of the above mentioned codices can help to discover the intellectual background of certain cultural institutes. The codex dated to the end of the $14^{\text {th }}$ century, and contains five texts. ${ }^{61}$ The first is an apocryphal writing, which title is Tabulae Moysi et Abacuc de creatione angelorum, and unfortunately that is all known information about it. The next text is a short treatise about the wise words of the Church fathers on the seven deadly sins. Besides the significant thinkers of the time of the Church Fathers, like Saint Augustine, Saint Jerome or Saint Gregory the Great we can read the thoughts of historians (like Cassiodorus) and ancient philosophers (e.g. Seneca, Socrates) also in this manuscript. The text informs its reader that collectae in castro Pragensi, which means that the original version of the text was compiled in Prague. ${ }^{62}$ According to the database of the Europeana this text is followed by the Summa de casibus et poenitentiae of Innocent IV. As the inscription in the recto of folio 126 says: "explicit scriptura Innocentii quarti sub anno domini M CCCXC quinto [...]." However, this inscription is clear, Pope Innocent IV never wrote a text like this. Moreover the dating of this writing is not accurate in the literature, as one can read 1393-1394, and even $1294 .{ }^{63}$ While the manuscript explicitly certifies the 1395 as the year of completion. It was important to be noted, since the next part of the codex dated to 1393. More problematic that the text can't be related to Pope Innocent. Julius Sopko also noticed this and identified the text as the Summa de poenitentia of Thomas de Chobham, while the earlier

57 Ibidem.

58 AJP, p. 32. Tř́ǏŠKA, ref. 5, p. 383.

59 AJP, p. 30.

60 TǨ́ÍSKA, ref. 5, p. 385. Tříška in another work of him mistakenly connected this Nicolaus de Czypcz to those, who made his last will in 1439, because the latter studied in Cracow from 1419. TŘÍŠKA, 1967, p. 128. See: KELÉNYI, Borbála. A Krakkói Egyetem magyarországi diákjai. In HARASZTI SZABÓ, Péter - KELÉNYI, Borbála - SZÖGI, László (eds.). Magyarországi diákok a prágai és a krakkói egyetemeken 1348-1525 II, Budapest: MTA TKI-Egyetemtörténeti Kutatócsoport - ELTE Levéltára, 2016, (Under print).

61 http://www.europeana.eu/portal/hu/record/9200463/BibliographicResource_3000148674207. html (National Library of Romania, Batthyaneum, Ms II 65).

62 SOPKO, ref. 28, p. 369.

63 See the database of Europeana in the quot. 60, while Mârza dated it to 1394. MÂRZA, Eva Selecká. A középkori lócsei könyvtár. Szeged: Scriptum, 1997, pp. 77; Sopko dated to 1393-1394. SOPKO, ref. 28, p. 369. 
literature hadn't taken notice on this question. ${ }^{64}$ One could find a short extract of this work of Chobham in a codex of the National Library of the Czech Republic, ${ }^{65}$ which tell us that the original work of Chobham contained 227 chapters. This number is similar to those 233 which was mentioned in the examined codex. The next writing is the fourth book the Sententiae of Pertus Lombardus. The last text was written about the immorality that can be committed by the consorts. These texts were certainly useful for the clergy.

An inscription testifies that one of the texts in this codex was copied in Prague. One of the Hungarian students could have been the copier, since the codex get to Levoča later, so he might have come from the Spiš region. Georgius de Foro Caseorum and Nicolaus Feystrip de Czypcz can be considered as the copier, although only the latter got in closer connection with the libraries of Levoča. Feystrip was a well-known member of the "cultural and scholarly" life of Spiš. He was a priest of the Saint George Chapel of the Saint Jacob parish church in 1405 , furthermore he was a librarian with his three fellows at the library of the confraternity of the 24 parish priests of Spiš. ${ }^{66}$ Feystrip studied at Prague in 1392 at the Law University, while one year later one can find him at the Faculty of Arts, when he get the bachelor degree ${ }^{67}$ together with Georgius de Foro Caseorum. ${ }^{68}$

The rootlet of this book has a vignette which links to Levoča. There is no further information on the establishing, development or the early times of the library. An inscription dated to 1405 in a $14^{\text {th }}$-century codex informs us firstly about this library. According to Zsigmond Jakó the medieval libraries of Hungarian parish churches were established from the turn of the $14^{\text {th }}$ and $15^{\text {th }}$ centuries. ${ }^{69}$ The handwritten codices were very expensive, thus their making and purchasing needed financial sacrifices. The bookmaker workhouses near to the medieval universities or the universities themselves made easier to acquire books. It worth to note at this point that the peregrination of the Hungarian parish priests and the lower clergy only began in the $14^{\text {th }}$ century, which is an important observation of the peregrination-researches. In my earlier researches I noticed, that though the first parish priests - like the majority of the students - studied in Italy (exactly three persons: John from the parish church of Sibiu, ${ }^{70}$ Paul from Óbuda ${ }^{71}$ and William of $\mathrm{Cifer}^{72}$ ), they came from a prosperous parish church or were supported by

\footnotetext{
${ }^{64}$ VARJÚ, Elemér. A gyulafejérvári Batthyány-könyvtár, V. közlemény. In Magyar Könyvszemle, 1900, vol. 8, no. 2, p. 165.

65 National Library of Czech Republic, XIX C 49, fol. 49v.

${ }_{66}$ MÂRZA, ref. 63, p. 30.

67 LDPP I., p. 288.

68 HARASZTI SZABÓ, Péter. A prágai egyetem hallgatói Luxemburgi Zsigmond magyar királyi udvarában. In FÁBIÁN, Laura - GÁL, Judit - HARASZTI SZABÓ, Péter - UHRIN, Dorottya (eds.). Micae Mediaevales V. Fiatal történészek dolgozatai a középkori Magyarországról és Európáról. Budapest: ELTE BTK Történelemtudományi Doktori Iskola, 2016, pp. 69-91.

69 JAKÓ, Zsigmond - MANULESCU, Radu. A latin írás története. Budapest: Európa, 1987, pp. 127-128.

70 VERESS, Endre. Olasz egyetemeken járt magyarországi tanulók anyakönyvei és iratai (12211864). Budapest: Római Magyar Történeti Intézet, 1941, p. 394.

71 VERESS, ref. 70, p. 28.

72 VERESS, Endre. Matricula et acta Hungarorum in universitatibus Italiae studentium I. Padua 1264-1864. Kolozsvár: Stephaneum, 1915, p. 2.
} 
a wealthy patron. On the other hand, the number of parish priests who get to the universities were outstanding from the 1370s thanks to the new universities founded in Prague and Vienna. ${ }^{73}$ It resulted that the parish priests became the greatest group of the ecclesiastical officeholders at the foreign universities' law faculties under the rule of King Sigismund. The same process took place with altarists, chaplains and with some restrictions with the simple clerics, too. In other words, the peregrination of these layers and the appearance of the first libraries at Hungarian parish churches can be paralleled with the Central European University foundations from the second half of the $14^{\text {th }}$ century. In the light of this presumption the foundation of the library of the confraternity happened in the last third of the $14^{\text {th }}$ century. According to Eva Selecká Mârza the location of this library cannot be found. ${ }^{74}$ Although the author of this article agrees with Elemér Varjú, who said that the library must had been in Levoča. ${ }^{75}$ From the first four known librarians Feystrip was a priest of the Saint George Chapel, which also functioned as the library of the parish church in the Middle Ages which strengthens Varjú's hypothesis. Furthermore, Varjú stated that the library was founded in 1405 by George parish priest of L'ubica, who also was one of the first librarians. ${ }^{76}$ On the whole, the examined book (or just some part of it) of Feystrip also ensures that the library of the Saint George Chapel and the library of the Confraternity were founded at the end of the $14^{\text {th }}$ or the very beginning of the $15^{\text {th }}$ century, after the greater waves of the peregrination of the lower clergy (such as parish priests or altarist) had begun. The students brought home manuscripts and codices from the universities which supported them in the daily activities, liturgy and to guide their community. They created the first libraries of the parish churches from these writings, following the example of the chapter libraries. Thus obviously the Central European universities, especially the one in Prague had great role in the development of the Hungarian cultural life.

\section{A provost of Veszprém at the University of Prague?}

The copier or the provenience of a manuscript is not certain in every case, sometimes the Praguean origin is just assumed, like in the case of a codex dated to the second half of the $14^{\text {th }}$ century. ${ }^{77}$ The codex contains the biography of archbishop of Prague, Arnošt z Pardubic which confirms the presumed origin, since this writing was not enjoyed great popularity outside the Kingdom of Bohemia. Moreover this manuscript was written shortly after 1364, when the archbishop died. A short inscription leads to this conclusion on the recto of folio 15. On the top of this page there is a three-lined writing, which is unfortunately unclear.

73 The next parish priest after them studied in Prague in 1375: Leo de Magno Horreo and Tilmannus de Villa Humperti. Although Leo was the brother of the bishop of Transylvania, Tilmannus could reckon only on his own parish. AJP, p. 31.

74 MÂRZA, ref. 63, p. 30.

75 VARJÚ, Elemér. A gyulafejérvári Batthyány-könyvtár, II. közlemény. In Magyar Könyvszemle, 1899, vol. 7, no. 3, p. 214.

76 VARJÚ, ref. 64, p. 150.

77 National Library of Romania, Batthyaneum, Ms II 45. 
Varjú considers that this was only a pen-exercise. ${ }^{78}$ The upmost line mentions a certain provost John, the name place of his provostry unreadable. Under this line the name of John, provost of Veszprém was written. Only two provosts held this name in Veszprém from the second half of this century. One of them was the provost of the All Saints collegiate chapter in $1377,{ }^{79}$ while the other was the provost of Saint Michael cathedral chapter, who was even known as baccalaureus decretorum in 1369. ${ }^{80}$ And because this John was provost until 1382, the manuscript also had to be written until this year. Although one cannot find anyone who gained this title and named to John in this period, according to the collected information of the History of Universities Research Group. Only John archdeacon of Eger considered who studied at the University of Padua, but he appeared at this university in October of $1367,{ }^{81}$ while there are information of the provost of Veszprém from July of this year. From all of this we presume that John also studied at Prague, at the Faculty of Law, but there are not exact evidences about this. The sources of the Law University (before 1372, the Faculty of Law) are entirely missing before 1372, thus the fact that Johns name is missing from the remained sources doesn't confute the assumption, since he had to get his degree before the crucial year of 1372. Furthermore the name of the manuscript's copier (Petrus Crispus, fol. 64r.) is known. This fact does not reduce the possibility of my hypothesis, because Laurentius Zambo also hired a copier, he didn't make his manuscripts with his own hands. Besides the biography of the archbishop the codex contains the sermons of the Franciscan friar Lucas de Bitonto and a work entitled Expositio psalmorum poenitentialium, too. Unfortunately all these facts and assumptions don't explains how the codex get to Levoča.

\section{The Summa Britonis and its copier}

As it was mentioned above, there are three philosophical texts in the examined group, although the third can be treated as a theological text, too. This codex dated to 1377 and contains the $11^{\text {th }}$-century lexicographers, Papias' biblical dictionary, the De summo bono from Isidore of Seville, while in my perspective the third writing is the most interesting, that is another biblical dictionary from Guillelmus Britonis. ${ }^{82}$ This book, known as Summa Britonis was written in the second half of the $13^{\text {th }}$ century by the Franciscan friar Guillelmus Britonis, who studied at the University of Paris. ${ }^{83}$ He collected and interpreted the hardest words of the Vulgate, around 2500 entries. Brito used the works of Papias, Isidore of Seville, which texts are also remained in this codex. Moreover, he used the work of Huguccio of Pisa as well as Greek, Hebrew and some other writings from the time of the Church Fathers, too. It would not be extraordinary to classify this work to the philosophical texts, because

78 VARJÚ, ref. 64, pp. 149-150.

79 C. TÓTH, 2013, p. 73.

80 KARLINSZKY, Balázs. A veszprémi nagyprépostok archontológiája, 1079-1543 - Három prépost portréjával. In Turul, 2014, vol. 87, no. 3, p. 95.

81 VERESS, ref. 70, p. 152.

82 National Library of Czech Republic, X B 5.

83 DALY, Lloyd W. - DALY, Bernardine A. (ed.). Summa Britonis sive Guillelmi Britonis expositiones vocabulorum biblie. Patavii: In aedibus Antenoreis, 1975, XIII-XVIII. 
for instance along with Papias and Huguccio of Pisa the work of Brito sometimes was labelled as philosophical writing, like at the library of the Cistercian cloister of Clairvaux in 1472, where this texts belonged to the artium et philosophiae section and within this to the grammatical texts. ${ }^{84}$ This work of Brito was very popular in Hungary, too. Almost 20 copies is known from the medieval Hungarian libraries, most of them are incunables, only three handwritten manuscript have remained, from which two are just fragments from the $13^{\text {th }}$ century, ${ }^{85}$ while the third is a fragment also from 1428. ${ }^{86}$ This version from 1377 fascinating not just because this is a whole version, but because we know the copier, too. On the folio 119 one can read this hardly explainable registry: Explicit Brito finitus per recerendum Budam anno millesimo trecentesimo septuagesimo septimo. This makes clear that the copier was an ecclesiastical, but the lack of the first name generates several problem. It has been suggested that the name "Buda" is a Slavic personal name, or the copier came from a certain "Buda" place in the Slavic speech area. But after the overview of some Czech and Polish sources, moreover, consulting with some Czech colleagues, ${ }^{87} \mathrm{I}$ had to dismiss this option. Another opportunity is that the copier can be found among the students came from the Hungarian capital, Buda to the University of Prague. This problematic explicit makes probable that a Hungarian person with the first name of "Buda" was the copier. According to the relevant researches of History of Names only five Buda is known from the total 20000 items, and each of them were laymen in the first half of the Angevin age of Hungary. ${ }^{88}$ At this point we have to turn back to the students of Buda at the University of Prague at this time. Two students come into question: Nicolaus de Buda, who studied at the Law University in 1377 and Johannes de Buda, who were educated in Prague from 1374, where he later became a professor of the Facultas artium. ${ }^{89}$ Both of them could be the copier of this manuscript regarding the dating of the text, but considering the further goal of this text, namely the explanation of Bible, this work much more suits to the profile of Johannes de Buda who later founded the Collegium Christi in Esztergom. Although this isn't explain the strange form of the name in the inscription. In the contemporary use of names we found name-types without " $\mathrm{de}^{\text {" }}$ preposition (so called "pure place names") $)^{90}$

84 NEBBIAI-DALLA GUARDA, Donatella. Les glossaires et dictionaires dans les bibliothèques médiévales. In HAMESSE, Jacqueline (ed.). Les manuscrits des lexiques et glossaires de l'Antiquité tardive à la fin du Moyen Âge. Actes du Colloque international organisé par le "Ettore Majorana Centre for Scientific Culture" (Erice, 23-30 septembre 1994). Louvain-la-Neuve: Fédération internationale des instituts d'études médiévales, 1996, pp. 180-181.

85 SOPKO, I. 13.; At the same time there was another manuscript in the beginnings 15th century at the Chapter of Veszprém: Csapodi III. No. 989.; No. 1044. Stephanus Engkel de Cluswar also owned one in 1453: CSAPODI III. No. 1917. The dominican convent of Košice also: CSAPODI III. No. 2478.

86 SOPKO, I., p. 47.

87 I would like to express my gratitude to Pavel Soukup for his help in this question!

88 SLÍZ, Mariann. Anjou-kori személynévtár, 1301-1342. Budapest: Históriaantik, 2011, p. 65.

89 KÖRMENDY, ref. 12, pp. 63-66, 69, p. 182. C. TÓTH, ref. 12, p. 95.

90 TÓTH, Valéria. Gondolatok a helynévi eredetú személynevekről, Helynévtörténeti tanulmányok, 11 (2015), pp. 127-130; GULYÁS, László Szabolcs. Újabb adatok a középkori jobbágyimezővárosi személynévadás kérdéséhez.= Névtani értesítő 31 (2009), p. 57. GULYÁS, László Szabolcs. Personal names and society in medieval Hungarian cities and market-towns, In TORT I DONADA, Joan - MONTAGUT I MONTAGUT, Monserrat (eds.). Els noms en la vida quo- 
in several times, ${ }^{91}$ like in the Dean's Book of the Faculty of Arts and the remained sources of the University of Law also contains several Hungarian students with this name form. ${ }^{92}$ In this case the "Johannes Buda" name form allow us the supposition that the copier was the founder of the Christ College. Unfortunately I have not found this form of his name in the Hungarian archival sources, though this isn't exclude this solution. Another option is that the copier used both John and Buda first name alternatively. ${ }^{93}$ Unfortunately we couldn't prove any option with linguistic methods, while the lack of sources and the explicit reduce the opportunity these solutions. ${ }^{94}$ On the other hand I have found a nearly contemporary data from 1394 among the codices of Nagyszeben (Sibiu, RO). This codex contains a similar (nearly the same) inscription like in the questionable case: the writer tell us, that this book "pertinent ad fraternitatem per cybinium, ${ }^{95}$ " while later the scripter introduced himself by Theodericus. If the copier' intention was to inform us that the codex belongs to the Fraternity of Sibiu, in that case he must had to say it with another grammatical structure. On the top of that János Csontosi found a certain magister Theodericus among the bookmakers of the chapter of Sibiu at the very beginning of the $15^{\text {th }}$ century. Thus Csontosi made the supposition very similar that the scripter of the manuscript and the bookmaker of Sibiu was one and the same. ${ }^{96}$ Furthermore the compiler was Michael plebanus in Parvo Horreo, and this little Saxon town located in the neighbourhood of Sibiu also. This analogy also make my opinion probable that reverend Buda is equal with Johannes de Buda. There is a more serious reason why possible that "reverendus Buda" is identical with Johannes de Buda, namely that the oldest catalogue of the library of the College of the Bohemian Nation' contains this manuscript. ${ }^{97}$ Belonging to a university nation does not tell us anything, like Nicolaus and Johannes de Buda also belonged to the Bohemian academic nation. However, the mentioned nation's college was founded almost a decade after John of Buda left Prague. ${ }^{98}$ Despite of this he had connections with its founder, Johannes Venceslai de Praga. First of all, he presented John of Buda to the University of Prague in 1374. Moreover, Johannes Venceslai de Praga founded a library for the college from his own books. ${ }^{99}$ How this book get to the

tidiana. Actes del XXIV Congrés Internacional d'ICOS sobre Ciències Onomàstiques. Names in daily life. Proceedings of the XXIV. ICOS International Congress of Onomastic Sciences. Generalitat de Catalunya, Barcelona, p. 1729.

91 For examples see: Magyar Nemzeti Levéltár Országos Levéltár DL 26589.; Zichy V. 156. NAGY, Imre - NAGY, Iván - VÉGHELY, Dezső - BARABÁS, Samu - KAMMERER, Ernő - LUKCSICS, Pál - DŐRY, Ferenc (eds.). A zichi és vásonkeői gróf Zichy-család idősb ágának okmánytára I-XII. Budapest: 1871-1931. V. No. 156.

92 AJP 119. LDPP I. 305, 320, 366, p. 416.

93 Thanks to the advice for Valéria Tóth and László Szabolcs Gulyás!

94 I would like to express my gratitude to Slíz Mariann for her help in linguistic questions!

95 CSAPODI - CSAPODINÉ, II. No. 2049a.

96 CSONTOSI, ref. 33, pp. 46-47.

97 BECKÁ, Josef - URBÁNKOVÁ, Emma (eds.). Katalogy Knihoven Koleji Karlovy University. Praha: Univerzita Karlova, 1948, p. 9.

98 SVATOŠ, ref. 40, pp. 52-53. The date 1490 must be a mistyping, because the collegium was founded in the 1390s.

99 TŘÍŠKA, ref. 5, pp. 321-322. 
library? Considering that the copier was Johannes de Buda, he might have given his manuscript to Johannes de Praga, when he left Prague. Buda as a first name is rare in the Hungarian archival sources, as well as among the 12 thousand medieval Hungarian university students, too (one cannot found any Buda among them). Thus it is still possible that Johannes de Buda was the copier, however it's just an assumption. It have to be mentioned as a curiosity, that John's student, the already mentioned Thomas de Pijesczano copied a work which is similar to the examined codex (the Catholicon of Johannes Balbus), what he bequeathed to the cathedral chapter of Esztergom. ${ }^{100}$

\section{Conclusion}

In the focus of the interests of the Hungarian students at the University of Prague were not the philosophical texts, in spite of the fact that most of them studied at the Faculty of Arts. From the examined texts we could draw the conclusion that the Hungarian students had strong theological interests, since more than the half of the remained and known manuscripts/copies belonged to this discipline. Presumably - despite of the lack of sources - there were Hungarian theology students in the Czech capital. Another observation is that through these texts the Hussite theories couldn't find its way to Hungary. Only one fragments might have connected to the Hussitism, the so-called "Hussite Bible", but this is one of the most problematic writing from the point of view of its birthplace and time, and mostly of its translators. The theological manuscripts usually were copied in order to help the priests to guide the believers in their everyday life and to help them in other church matters. The legal texts of Lawrence Zámbó also points to this way of use. It is worth to note at the same time, that the Prague-related writings, like the legal texts of Provost Lawrence and the Processus iudiciarius played important role at the ecclesiastical judicial seats in the archdiocese of Esztergom. Possibly, Provost John of Veszprém (1367-1382) also learned law at Prague in the 1360s, but this is only an assumption. The two most important codices related to Nicholas Feystrip and to the "Reverend Buda". The analysis of Feystrip's codex revealed the cultural roots (at least from one direction) of the library of the Fraternity of 24 Spiš' parish priests. While the manuscript of Reverend Buda could be linked to the founder of the Collegium Christi, or this manuscript belongs to a Hungarian student who is not know yet. Thus the further researches need to clarify the connection between Prague and some Hungarian educational or other cultural institutions, like the Collegium Christi, as well as the medieval Hungarian university foundations.

Words: 8116

Characters: 51241

${ }^{100}$ KÖRMENDY, Kinga. A kánonjog középkori egyetemi oktatásával és a 15. századi esztergomi vikáriusok olvasmányaival, múködésével kapcsolatos kéziratos források az esztergomi egyház 1543 előtti könyvállományában. In ERDŐ, Péter (ed.). Tanulmányok a magyarországi egyházjog középkori történetéről, Budapest: Szent István Társulat, 2002, p. 182. 